\author{
Stanisław Liszewski \\ Katedra Geografii Miast i Turyzmu \\ Uniwersytet Łódzki \\ 90-142 Łódż \\ ul. Kopcińskiego 31 \\ miastur@geo.uni.lodz.pl
}

\section{REGION TURYSTYCZNY}

\begin{abstract}
Zarys treści: Po omówieniu dotychczasowego dorobku naukowego w zakresie pojęcia i delimitacji regionu turystycznego, autor zaproponował własna, oryginalną definicję regionu jako przedmiotu poznania. Podstawą tej definicji uczynił autor koncentracje ruchu turystycznego, a następnie wydzielił siedem typów funkcjonalnego regionu turystycznego.
\end{abstract}

Słowa kluczowe: region turystyczny, funkcjonalny region turystyczny, turystyczny region metropolitalny, peryferyjny, węzłowy, pasmowy, wielkoprzestrzenny, wyspecjalizowany i wielofunkcyjny.

\section{WSTEP}

Podejmując rozważania i dyskusję na temat istnienia regionu turystycznego $\mathrm{i}$ jego definicji, należy przypomnieć kilka, jak się wydaje, prawd oczywistych, które legły u podstaw rozwoju współczesnej turystyki.

1. Przestrzeń geograficzna naszej planety jest bardzo silnie zróżnicowana $\mathrm{i}$ to pod wieloma względami. Należy tu zwłaszcza wymienić zróżnicowanie środowiska przyrodniczego, przeszłość historyczną, zróżnicowanie etniczne i kulturowe, religijne, gospodarcze i inne.

2. Współczesny człowiek coraz częściej odczuwa potrzebę podróżowania w celach pozazawodowych. Potrzeby te wzrastają wraz z dynamicznie postępującym procesem urbanizacji i koncentracją ludności w wielkich skupiskach miejskich. Motywy tej potrzeby podróżowania tkwia zarówno w pragnieniu poznania zróżnicowanego świata, jak również konieczności regeneracji sił fizycznych i psychicznych, a także odnowy duchowej. Ta potrzeba podróżowania czyni z człowieka współczesnego nomadę przemieszczającego się z miejsca na

\section{THE TOURIST REGION}

Outline: Having discussed the academic achievements regarding the notion and delimitation of the tourist region, the author suggests his own original definition. $\mathrm{He}$ has based this definition on the concentration of tourist, and then isolated seven types of functional tourist region.

Key words: tourist region; functional tourist region: metropolitan, peripheral, nodal, linear, large-scale, specialized and multi-functional tourist regions.

\section{INTRODUCTION}

In opening a discussion about the tourist region and its definition one should refer to several obvious facts fundamental to the development of modern tourism.

1. The geographical space of our planet is in many respects strongly diversified. We should mention here the varied natural environment, the historical past, and ethnic, cultural, religious, economic and other differences.

2. Contemporary man more and more frequently feels the need to travel for purposes other than work. This need has grown alongside the dynamic progression of urbanization and the increase in population of large urban centres. The motives for travel are rooted in human interest in the surrounding world, and in the need to regenerate physically, psychologically and spiritually. This urge to travel makes contemporary man a nomad 
miejsce, tym razem nie $w$ poszukiwaniu pożywienia, ale poznania i wypoczynku.

3. Migracje turystyczne stają się coraz łatwiejsze i obejmują coraz większy krąg mieszkańców świata, a sprzyja temu i ułatwia podróżowanie rozwój środków komunikacji oraz szeroko rozumianej infrastruktury turystycznej (zagospodarowanie turystyczne).

Powstaja zatem pytania. Czy potoki migracji turystycznych rozkładają się równomiernie na całej przestrzeni geograficznej, czy też koncentrują się na określonych tylko obszarach? O ile zachodzi ta druga sytuacja, to gdzie znajdują się te obszary i dlaczego właśnie tu następuje koncentracja przyjazdów turystycznych? Inaczej mówiąc, są to pytania o istnienie regionów turystycznych rozumianych jako część ogólnej przestrzeni geograficznej, na której koncentruje się szeroko rozumiany ruch turystyczny (sensu largo). Poszukiwanie odpowiedzi na tak postawione pytania jest zarazem poszukiwaniem regionu turystycznego rozumianego i definiowanego w ujęciu funkcjonalnym.

\section{PRZEGLAD DEFINICJI REGIONU TURYSTYCZNEGO}

Historia pojęcia regionu turystycznego jest tak długa, jak zjawisko nazywane turystyką i związane jest ono zarówno z potocznym określeniem obszarów, na które przemieszczał się człowiek w celach wypoczynkowych (zdrowotnych, religijnych itd.), jak również z badaniami naukowymi, jakie podjęto nad turystyką w XX w. W tym pierwszym, potocznym znaczeniu, nie definiując precyzyjnie obszarów wypoczynkowych, określano je zwykle nazwą krajobrazową. Wyjeżdżano „w góry”, „nad morze”, ,nad jeziora”, czy bardziej szczegółowo np. ,na Podhale”, „, na Kaszuby” czy „,na Lazurowe Wybrzeże". Nazwy tych potocznie określanych regionów turystycznych były często zapożyczone z geografii, historii czy etnografii.

Podjęcie badań naukowych nad szeroko rozumianą turystyką wymusiło na badaczach stworzenie $w$ miarę precyzyjnego aparatu pojęciowego, który odpowiednio zdefiniowany umożliwił podjęcie studiów teoretycznych i aplikacyjnych.

Jednym z takich pojęć wymagających pilnego zdefiniowania stał się region turystyczny.

Celem tego opracowania nie jest wyczerpujący przegląd definicji regionu turystycznego, dlatego przywołamy tu tylko niektóre $\mathrm{z}$ występujących moving from place to place, this time not in search of food but knowledge and recreation.

3. Tourist movement is becoming easier and involve a growing number of the world's inhabitants. Travelling is facilitated by the development of means of transport and a tourist infrastructure.

As a result some questions arise. Is tourist movement distributed evenly throughout geographical space, or is it concentrated in certain areas only? If the latter is true, then where are these areas and why do they attract tourists? In other words, these are questions about tourist regions as part of general geographical space, where tourism sensu largo is concentrated. Searching for answers to these questions means searching for a tourist region which is to be understood and defined functionally.

\section{DEFINITIONS OF THE TOURIST REGION - A REVIEW}

The notion of the tourist region is as old as the phenomenon called tourism, and refers both to the popular name for areas where people travelled in order to rest, get healthy or pray, and to the academic research into tourism begun in the $20^{\text {th }}$ c. In the first, popular sense, recreational areas were named using 'landscape' terms avoiding precise definition. People travelled to 'the mountains' 'the seaside', 'the lakes', or more precisely e.g. to Podhale, Kaszuby, or the Cote d'Azur. These popular names were often taken from geography, history or ethnography.

The task of conducting research into tourism sensu largo forced academics to create a fairly precise set of terms in order to carry out theoretical and applied studies. One of the notions which required a precise definition was that of the tourist region. The aim of this article is not to provide a detailed review of definitions so only some that occur in the Polish literature will be mentioned in 
w polskiej literaturze definicji, aby przybliżyć tok myślenia ich autorów.

Jedna $\mathrm{z}$ pierwszych, $\mathrm{w}$ okresie powojennym, definicji regionu turystycznego zaprezentowała MILESKA (1963) w pracy poświęconej regionom turystycznym Polski i ich delimitacji. Autorka tej pracy uważa, że „Region turystyczny to obszar o wysokich walorach turystycznych, na którym koncentruje się ruch turystyczny". Jak wynika z treści pracy Mileskiej, walory turystyczne (głównie przyrodnicze) były cechą najważniejszą przy delimitacji regionu (region potencjalny), a ich zagospodarowanie turystyczne umożliwiło zorganizowanie ruchu turystycznego (region rzeczywisty). Przypominając tę definicję musimy pamiętać, że W okresie jej powstania w Polsce rozwijała się tzw. zorganizowana turystyka socjalna, a ruchliwość przestrzenna mieszkańców naszego kraju $w$ dużym stopniu uzależniona była od masowych środków komunikacji (kolej, autobus kursowy bądź wycieczkowy).

Bardzo podobnie definiuja region turystyczny BAR i DoLIŃSKI (1974), dla których, jest to obszar (część kraju) charakteryzujący się walorami turystycznymi oraz odpowiednimi do nich walorami recepcyjnymi, do którego kieruje się ruch turystyczny". Wydaje się, że w przypadku tej definicji znaczącym wyznacznikiem regionu turystycznego stały się „,walory recepcyjne”, które wprawdzie obejmują znaczną część infrastruktury turystycznej, z wyraźną jednak dominacją bazy noclegowej.

Inne podejście przy określaniu regionu turystycznego prezentuja autorzy pierwszego polskiego podręcznika akademickiego do geografii turyzmu WARSZYŃSKA i JACKOWSKI (1978), którzy uważają że „Jako region turystyczny można traktować obszar pełniący funkcję turystyczną na zasadzie pewnej jedności cech środowiska fizycznogeograficznego oraz wewnętrznych powiązań usługowych". W definicji tej po raz pierwszy spotykamy się z podejściem funkcjonalnym, co przejawia się w zaakcentowaniu funkcji obszaru nazywanego regionem turystycznym. W dalszej części pracy tych autorów znajdujemy pewne doprecyzowanie pojęcia „region turystyczny”. Piszą oni „Jest więc region turystyczny tworem przestrzennym opartym na przesłankach wynikających z walorów środowiska naturalnego oraz działalności społeczno-ekonomicznej”, i dalej: „Regiony turystyczne mają charakter integrujący, a pod względem hierarchicznym stanowią systemy złożone".

$\mathrm{Z}$ analizy określeń WARSZYŃSKIEJ i JACKOWSKIEGO (1978) wynika, że autorzy ci definiują re- order to shed light on their authors' ways of thinking.

One of the first which appeared after World War II, was presented by MILESKA (1963) in her work devoted to tourist regions in Poland and their delimitation. The author believed that "a tourist region is an area with valuable tourist assets where tourism concentrates". Tourist assets (mainly natural) are considered to be the most important for delimiting a region (a potential tourist region), while the infrastructure enables tourist activity (an actual tourist region). In recalling this definition, we must remember that at the time it appeared organized welfare tourism had developed in Poland, and tourist mobility largely depended on public means of transport, like the railway, coach or bus.

The tourist region is defined similarly by BAR \& DOLINSKI (1974) for whom it is "an area (part of the country) characterized by tourist assets and corresponding reception assets where tourist flows are directed". It seems that in this definition, the important markers of a tourist region are the reception assets', which cover a considerable part of the tourist infrastructure with clear domination given to hotel accommodation capacity.

A different attitude is represented by the authors of the first Polish textbook for students of tourism, WARSZYŃSKA \& JACKOWSKI (1978) who believe that "a tourist region is an area performing a tourist function, based on a certain homogeneity of the physical-geographical environment and an interlinked service system". In this definition we first encounter the functional approach showing emphasis on the functions of a tourist region. Further on in the work we find more details concerning this notion, the authors write: "Thus a tourist region is a spatial entity based on natural assets and socio-economic activity. (...) Tourist regions are of an integral character, and their hierarchies are complex systems". The terms used by WARSZYŃSKA \& JACKOWSKI (1978) show 
gion turystyczny jako obszar wewnętrznie jednorodny (np. pod względem środowiska fizycznogeograficznego) i powiązany usługowo, który pełni funkcję turystyczną. Nowością w tym określeniu jest również uznanie istnienia hierarchiczności regionów turystycznych.

Znacznie bardziej „operacyjna” jest definicja regionu turystycznego sformułowana przez LIJEWSKIEGO, MIKUŁOWSKIEGO i WYRZYKOWSKIEGO (1985), autorów książki pt. Geografia turystyki Polski. Ich zdaniem „Regionami turystycznymi nazywa się większe obszary o jednakowym typie środowiska geograficznego (np. Wybrzeże, Pojezierze Mazurskie, Karpaty). Wydzielone w ich obrębie mniejsze jednostki nazywa się dla odróżnienia rejonami turystycznymi" (s. 193). Takie określenie regionu turystycznego bardzo ściśle nawiązuje do definicji M. I. Mileskiej, z jeszcze mocniejszym zaakcentowaniem typu środowiska geograficznego. Wydaje się, że jest to zbyt daleko posunięty determinizm środowiskowy, który w przypadku regionu turystycznego miał swoje uzasadnienie w początkowym okresie rozwoju turystyki, ale współcześnie chyba zbyt mocno zawęża to pojęcie.

Kończąc ten krótki przegląd definicji regionu turystycznego zacytujmy jeszcze określenie autorstwa LISZEWSKIEGO (2002): „Regionem turystycznym nazywa się stosunkowo jednorodny obszar, który wyróżnia się z otoczenia określonymi cechami naturalnymi lub nabytymi”, i dalej: ,region turystyczny to taki obszar, który charakteryzuje się atrakcyjnymi walorami turystycznymi, głównie naturalnymi oraz odpowiednim zagospodarowaniem, na którym koncentruje się ruch turystyczny. Ważną cechą określającą każdy region, w tym również turystyczny, jest jego wewnętrzna spójność i powiązanie, których intensywność wyznacza granice regionu".

Podsumowując zaprezentowany przegląd definicji warto postawić pytanie ogólne: czy pojęcie regionu (w tym przypadku turystycznego) jest konstrukcją wyłącznie teoretyczną (abstrakcyjna), czy też obiektywnie istniejąca rzeczywistością przestrzenną? Mówiąc inaczej, pytanie to dotyczy stwierdzenia, czy istnieje w rzeczywistości region turystyczny: o ile tak, to jakie sa jego cechy charakterystyczne?

Aby zakończyć tę serię pytań należy, konkretyzując wcześniej przedstawioną myśl, zacytować za CHOJNICKIM (1996) stwierdzenie Dumolarda „Regiony istnieją niezależnie od badaczy; muszą oni odkrywać je, a nie tworzyć" Czy dotyczy to również regionów turystycznych? that the authors define a tourist region as a geographically homogenous area with a system of interlinked services, and performing a tourist function. A new aspect in this definition is the hierarchical character of tourist regions.

Lijewski, Mikułowski \& Wyrzykowski, the authors of Geografia turystyki Polski (1985), offer a more operational definition. According to them, "Tourist regions are larger areas of the same type of geographical environment (e.g. the coast, the Mazurian lake district, or the Carpathian mountains). Smaller units contained in them are called tourist districts to avoid misunderstanding" (p. 193). Such a definition is closely related to Mileska's with an even stronger emphasis on the type of the geographical environment. This seems an excessive environmental determinism which, in the case of the tourist region, was justified in the early stages of tourism development but nowadays appears to narrow the notion down.

Closing this brief review, let us quote one more definition, that presented by LISZEWSKI (2002): "A tourist region is a relatively homogenous area which stands out from the surrounding environment due to its natural or acquired qualities. (...) A tourist region is an area with attractive tourist assets, mainly natural, and an appropriate infrastructure where tourist activity is concentrated. An important feature of every region, including a tourist region, is its inner unity and internal links which delimit the region's borders."

Summing up, let us pose a general question: is the notion of a tourist region exclusively theoretical (abstract), or is it an objectively existing spatial reality? In other words, does the tourist region really exist, and if so, what are its features? In order to end this series of questions, we should quote Dumolard (in CHOJNICKI 1996): "Regions exist irrespective of researchers who must discover, not create them". Does this thought refer also to tourist regions? 


\section{CECHY REGIONU TURYSTYCZNEGO}

Aby odpowiedzieć na pytanie, czy region turystyczny istnieje w sposób obiektywny, przyjrzyjmy się wpierw cechom opisującym region ekonomiczny, najbliższy, jak się wydaje, regionowi turystycznemu, szukając $w$ nich różnic lub podobieństw działalności turystycznej w przestrzeni geograficznej.

Kazimierz DZIEWOŃSKI (1967) wyróżnia trzy sposoby rozumienia pojęcia regionu ekonomicznego. Region jako narzędzie badacza - przykładem może być tutaj region statystyczny (DOMAŃSKI 1977); region jako narzędzie działania, czyli wytyczony do celów organizacyjnych (region planistyczny, region administracyjny), i wreszcie region jako przedmiot poznania. To ostatnie pojęcie odnosi się właśnie do pytania, czy region turystyczny istnieje obiektywnie, i jest głównym przedmiotem naszych rozważań. Należy tu jeszcze przypomnieć, że w odniesieniu do turystyki dwa wcześniej wymienione znaczenia regionu są powszechnie stosowane, zarówno w pracach badawczych (GOEEMBSKI 2002), jak w pracach planistycznych (RoGALEWSKI 1977).

Definiując główne cechy regionu, na plan pierwszy wysuwa się zwykle tezy główne: jednorodność w zakresie określonych kryteriów, zwartość przestrzenna oraz spójność i powiązanie wewnętrzne. Czy cechy te mogą również identyfikować region turystyczny?

Region turystyczny jako jedna $\mathrm{z}$ form podziału funkcjonalnego przestrzeni geograficznej posiada swoje cechy szczególne. Najbardziej charakterystyczną z nich, będącą wyznacznikiem wszelkiej działalności turystycznej w przestrzeni geograficznej, jest ruch turystyczny, rozumiany tu szeroko, czyli w sensie largo. W tym przypadku pojęcie turystyki musi obejmować zarówno tradycyjną (klasyczna) turystykę poznawczą, jak również turystykę wypoczynkową, zdrowotną, religijną, biznesową itd. Przyjmując zatem migracje turystyczne jako główną cechę regionu turystycznego decydujemy się na ujęcie funkcjonalne regionu jako przedmiotu poznania. Implikuje to konieczność weryfikacji cech regionu w ujęciu cytowanych wcześniej badaczy.

W świetle dotychczasowych rozważań, jako wątpliwa cecha regionu turystycznego jawi się jednorodność przestrzeni geograficznej, która u wielu wymienionych w pierwszej części tej pracy autorów była cechą dominująca. Obniżenie (ale nie wyeliminowanie) rangi tej cechy ogranicza w spo-

\section{CHARACTERISTICS OF THE TOURIST REGION}

In order to answer the question of whether a tourist region objectively exists, let us first look at the characteristics of an economic region, the closest it seems to a tourist region, looking in geographical space for differences and similarities to tourist activities.

Kazimierz DzIEWOŃSKI (1967) differentiates between three meanings of economic region: a region as a research tool (e.g. a statistical region; DOMAŃSKI 1977), a region as an operative tool for organizational purposes (planning, administrative region), and finally a region as an object of study. The last refers to the question of whether a tourist region exists objectively, and this is the main subject of our discussion. It should be remembered that the two former meanings of region are commonly used in reference to tourism both in academic research (GoŁEMBSKI, ed. 2002) and in planning (ROGALEWSKI 1977).

When defining the main characteristics of a region, we usually focus on the main assumptions: the homogeneity of selected criteria and spatial continuity, as well as inner unity and internal links. Can these characteristics also identify a tourist region?

The tourist region as a form of the functional division of geographical space has distinctive features. The most typical, which is a marker of all tourist activity in geographical space, is tourism sensu largo. In this case the notion of tourism must comprise traditional (classic) cognitive tourism, as well as recreational, health, religious, and business tourism. Thus accepting tourist movement as the main characteristic of the tourist region, the functional approach is chosen which requires a verification of the leading characteristics of the region according to the researchers mentioned earlier.

In the light of what we have said so far, homogeneity in geographical space seems doubtful as a characteristic of a tourist region, although it was per- 
sób dość zasadniczy determinizm przyrodniczy, który często sprowadzał region turystyczny do regionu fizycznogeograficznego, dodając do tego czynniki zagospodarowania turystycznego i dostępności komunikacyjnej. Przyjmując szerokie rozumienie ruchu turystycznego należy rozważyć, czy bardziej odpowiednią cechą regionu turystycznego nie byłaby różnorodność przestrzeni geograficznej, która zaspokaja potrzeby różnych grup turystów.

Pozostałe dwie główne cechy regionu, czyli jego zwartość przestrzenna oraz spójność i powiązania wewnętrzne, wydają się być ważnymi cechami również regionu turystycznego.

Eksponując w tych rozważaniach rolę ruchu turystycznego jako (miary) czynnika syntetyzujacego zjawisko nazywane turystyka, pragnę zaproponować określenie regionu turystycznego jako przedmiotu poznania.

Region turystyczny to taka część ogólnej przestrzeni geograficznej, na której koncentruje się ruch turystyczny (sensu largo).

Ta krótka definicja wymaga dodatkowych wyjaśnień, głównie o charakterze operacyjnym, które można ująć w kilku punktach.

1. Definicja ta odnosi się do regionu turystycznego w ujęciu funkcjonalnym. Miarą tej funkcji, a co za tym idzie podstawą definicji takiego regionu jest: wielkość, struktura, zasięg, sezonowość i natężenie ruchu turystycznego. Każda z tych cech ma swój udział w charakterystyce tak pojmowanego regionu. Przykładowo, natężenie ruchu turystycznego $w$ przestrzeni geograficznej może być podstawą określenia zwartości przestrzennej regionu, wielkość i zasięg geograficzny migracji turystycznych może posłużyć do wyznaczenia rangi regionu, a struktury demograficzna i społeczna wyznaczają spójność i powiązania wewnętrzne tego obszaru. Niewatpliwie najbardziej oryginalną cechą tak zdefiniowanego regionu turystycznego jest jego sezonowość, co oznacza, że natężenie funkcji turystycznej w przestrzeni geograficznej zmienia się w czasie w cyklu jednego roku.

2. Takie ujęcie regionu turystycznego nie uwzględnia „treści przestrzeni” ani przyrodniczej, ani kulturowej czy szerzej - antropogenicznej. Nie uwzględnia też stopnia zagospodarowania turystycznego czy pozaturystycznego tej przestrzeni. Jest to konsekwencją przyjętego na wstępie założenia, że syntetycznym miernikiem atrakcyjności przyrodniczej, kulturowej, zagospodarowania turystycznego i dostępności komunikacyjnej jest ceived as dominant by many of the authors mentioned before. Lowering (yet not eliminating) the rank of this characteristic considerably reduces the determinism which often identified a tourist region with a geographical one, while adding on infrastructure and transport accessibility factors. Assuming the broad sense of tourism, we should consider whether the variety of geographical space, providing for the needs of various tourist groups, would not be a more appropriate tourist region characteristic.

The remaining two characteristics of a region i.e. its spatial contiguity, as well as its inner unity and internal links, seem to be significant characteristics of a tourist region as well. Emphasizing the role of tourist movement as a synthesizing factor in tourism, I would like to propose to define a tourist region (as a object for study) as: that part of general geographical space where tourist movement (sensu largo) is concentrated.

This short definition requires additional operational explanations:

- The definition refers to a functional tourist region. The markers of this function, and consequently the grounds for the definition, are the range, structure, seasonality and intensity of tourism. Each of these characteristics is part of the description of the region. For instance, the intensity of tourism in geographical space may point to its spatial continuity, the geographical range of tourism may establish its importance, and the demographic and social structure determines its unity and internal links. Beyond any doubt, the most peculiar characteristic, defined in this way, is its seasonality, which means that the intensity of the tourist function in geographical space changes in time over an annual cycle.

- Such an approach to a tourist region does not include the contents of the space', natural, cultural or anthropogenic. Neither does it include tourist or non-tourist infrastructure development. This arises from the assumption 
ruch turystyczny i jego cechy. W tym znaczeniu region turystyczny jest częścią przestrzeni geograficznej, która przyjmuje ruch turystyczny. Jest to zatem obszar skonsumowanej podaży turystycznej.

3. Tak zdefiniowany region jest w pewnym sensie pojęciem ułomnym, nie uwzględnia bowiem potencjalnych walorów turystycznych a wyłącznie walory rzeczywiste, czyli te, które w określonym czasie koncentrują ruch turystyczny. Jest to zatem pojęcie racjonalne przy założeniu, że współcześnie walorem turystycznym może być każdy fragment przestrzeni geograficznej, co wynika z faktu dużego zindywidualizowania percepcji przestrzeni turystycznej.

Przyjęcie funkcjonalnego podejścia do regionu turystycznego praktycznie eliminuje pojęcie potencjalnego regionu turystycznego, bowiem każdy obszar uznany przez określoną grupę ludzi za interesujący i potwierdzony odpowiednio dużą migracją turystyczna, staje się regionem rzeczywistym. Uznanie obszaru za region uzależnione jest jednak od skali ruchu turystycznego i to pozostaje zagadnieniem otwartym.

4. Analizując rzecz historycznie, należy mieć świadomość, jak wielką rolę w kształtowaniu regionu turystycznego, w rozumieniu funkcjonalnym, odegrały walory przyrodnicze, zdrowotne, historyczne, kulturowe, zagospodarowanie turystyczne czy dostępność komunikacyjna. Wszystkie one miały i mają swój znaczący wkład w kreowanie obszaru, na który napłynęły potoki turystów czyniąc $\mathrm{z}$ niego funkcjonalny region turystyczny. Nie bez znaczenia będzie tu również uświadomienie trwałości tych obszarów jako regionów turystycznych, wynikających z tradycji i przyzwyczajenia, które są cechą zwłaszcza starszych pokoleń turystów. Uznając wartość i znaczenie walorów przyrodniczych w kształtowaniu regionów turystycznych należy jednak zdać sobie sprawę z obecnej skali migracji turystycznych i różnorodnych zainteresowań turystów, którzy coraz częściej podejmują swoje wędrówki z myślą o poznaniu nowych, do niedawna uznawanych za nieinteresujące, obszarów czy obiektów (np. zakładów przemysłowych), tworząc $w$ ten sposób nowe regiony turystyczne. Wydaje się również, że potwierdzeniem słuszności funkcjonalnego podejścia do regionu turystycznego jest koncepcja przestrzeni turystycznej przedstawiona $w$ pracach LISZEWSKIEGO (1995) oraz LISZEWSKIEGO i BACZWAROWA (1998). that the measure of natural and cultural attractiveness, tourist infrastructure and transport accessibility, is tourism and the features it produces. In this sense, the tourist region is a part of the geographical space which receives tourism. It is then an area of tourist supply.

- The region thus defined is in a way an incomplete notion as it does not include potential tourist assets, but only those actually existing which at a given time attract tourism. It is thus a rational notion, assuming that at the present time any part of geographical space can be a tourist asset, resulting from the fact that the perception of tourist space is largely individualized.

Accepting the functional approach practically eliminates the notion of a potential tourist region, because every area regarded as interesting by a given group of people, and featuring tourism, becomes an actual region. Whether we understand an area as a region, however, depends on the scale of tourism and this makes it an open issue.

Historically speaking, we should be aware of how important natural, health, historical and cultural assets, tourist infrastructure or transport accessibility have been in shaping a tourist region from a functional point of view. These elements have always played a significant part in creating the area where tourists are found, making it a functional tourist region. It should also be realized how stable these areas are, rooted in the tradition and habits of older generations of tourists in particular. Accepting the significance of natural assets for shaping tourist regions, we should realize, however, the present scale of tourism and the varied interests of tourists who increasingly often go on journeys to see new places or buildings which until now have been regarded as uninteresting (e.g. factory complexes). This way they create new tourist regions. The relevance of the functional approach is demonstrated by the tourist space concept presented in the publications by LISZEWSKI (1995), and LISZEWSKI \& BACZWAROW (1998). 


\section{TYPY FUNKCJONALNYCH REGIONÓW TURYSTYCZNYCH}

Przyjęta wcześniej definicja regionu turystycznego nie rozstrzyga o jego usytuowaniu, formie przestrzennej (kształcie) czy strukturze funkcjonalnej. Przyjmując wymienione cechy za kryteria zróżnicowania funkcjonalnych regionów turystycznych, możemy wydzielić kilka ich typów.

\section{A. Regiony turystyczne w zależności od ich usy- tuowania (położenia).}

Dzieląc przestrzeń geograficzną na obszary centralne i peryferyjne możemy wyznaczyć dwa główne typy regionów turystycznych: regiony metropolitalne oraz peryferyjne. Rozróżnienie to teoretycznie może mieć charakter globalny, praktycznie dotyczy jednak najczęściej jednostek politycznych o randze państwa.

Turystyczny region metropolitalny, zdaniem LISZEWSKIEGO (2002), powstaje $w$ otoczeniu dużych skupisk miejskich (metropolii), jako naturalny, najbliższy obszar wypoczynkowy, zwłaszcza wypoczynku codziennego i weekendowego, ale również urlopowo-wakacyjnego. Region metropolitalny obejmuje zarówno skupisko miejskie, jak i wspomniane wcześniej otoczenie, co powoduje jego wielofunkcyjność turystyczną. Obok funkcji wypoczynkowej w wielu tego typu regionach bardzo dużą rolę odgrywa turystyka poznawcza, kulturalna, kongresowa itd. Turystyczne regiony metropolitalne przyjmują najczęściej formę przestrzenną, która jest wymuszona dostępnością komunikacyjną, a także dostępnością prawną terenu, co powoduje, iż walory przyrodnicze nie zawsze odgrywają rolę wiodącą $w$ jego powstaniu. Ten typ regionów turystycznych rozwiną się w Polsce. Dlatego właśnie duże miasta można uznać za „przyczynę" kształtowania się takich regionów turystycznych. Interesującym przykładem powstania i ewolucji funkcjonalnego turystycznego regionu metropolitalnego jest Łódź, do niedawna typowe miasto przemysłowe, pozbawione znaczących zabytków historycznych, położone na obszarach mato atrakcyjnych pod względem przyrodniczym. Rozwój funkcji turystycznej rozpoczął się tu po pierwszej wojnie światowej powstaniem w otoczeniu Łodzi kilku modnych wówczas miast-lasów czy miast-ogrodów (miasto-ogród Sokolniki, Kolumna-Las, Tuszyn-Las, Grotniki, Wiśniowa Góra), które wykorzystywane były przez zamożniejszą część mieszkańców Łodzi jako miejsca wypoczynku letniego. Proces kolonizacji turystycznej

\section{TYPES OF FUNCTIONAL TOURIST REGIONS}

The adopted definition of a tourist region does not provide information about its location, spatial form (shape) or functional structure. Taking the characteristics mentioned above as criteria for differentiation, we can identify the following types of tourist regions:

\section{A. Tourist regions by location.}

Dividing geographical space into central and peripheral areas, we can identify two main types of tourist regions: metropolitan and peripheral. This differentiation may theoretically be global, but practically it usually concerns individual countries.

According to LISZEWSKI (2002), a metropolitan tourist region occurs around a large urban centre as an area primarily for daily and weekend recreation but also for holidays. The metropolitan region covers both the urban centre and its surrounding area which makes it touristically multifunctional. Next to its recreational function, many such regions serve purposes of cognitive, cultural and conference tourism. Metropolitan tourist regions are usually accessible and are constrained by numerous legal regulations, so natural assets do not always play a leading role in their creation. This type of tourist region in Poland has developed around large cities.

An interesting example of the emergence and evolution of a functional metropolitan tourist region is Łódz, a typical industrial city, situated in an unattractive natural area and until recently devoid of any historical monuments considered significant. The development of the tourist function here began after World War I when several fashionable 'forest-settlements' or 'garden-settlements' appeared around Łódź (Sokolniki, Kolumna-Las, Tuszyn-Las, Grotniki and Wiśniowa Góra), used by the richer inhabitants for summer recreation. The process of tourist 
obszarów podmiejskich nasilił się szczególnie po drugiej wojnie światowej i trwa do dzisiaj, obejmując obszary mało atrakcyjne przyrodniczo. Do tej funkcji wypoczynkowej dołączyła, zwłaszcza w ostatnich latach, funkcja poznawcza Łodzi (archeologia przemysłowa) oraz kulturalna, naukowa $\mathrm{i}$ handlowa (turystyka kongresowa, biznesowa itd.), czyniąc $z$ tego miasta i otaczającego go obszaru (strefy podmiejskiej) wielofunkcyjny, turystyczny region metropolitalny.

Turystyczny region peryferyjny. Nazwa tego regionu wskazuje, że jest to obszar funkcjonalnie związany z turystyka, znajdujący się w znacznej odległości od dużych skupisk miejskich, a więc peryferyjnie $w$ stosunku do nich. Zwykle powstanie turystycznych regionów peryferyjnych związane jest $\mathrm{z}$ atrakcyjnością walorów przyrodniczych; chodzi tu przede wszystkim o obszary nadmorskie, górskie, pojezierne, co pośrednio określa ich funkcję (wypoczynkową, krajoznawcza, zdrowotną itd.). Turystyka $w$ regionach peryferyjnych często kreuje jednostki osadnicze i to dużych rozmiarów (wybrzeże śródziemnomorskie Hiszpanii, czarnomorskie Bułgarii i Rumunii itd.), co rodzi poważne problemy ekologiczne i urbanistyczne na tych atrakcyjnych przyrodniczo terenach. Regiony peryferyjne przyjmują bardzo różnorodne kształty przestrzenne, różna jest też ich wielkość.

\section{B. Regiony turystyczne w zależności od formy przestrzennej (kształtu).}

Innym kryterium podziału funkcjonalnych regionów turystycznych na typy może być ich forma przestrzenna, czyli kształt. Wydaje się, że z tego punktu widzenia można wyróżnić trzy typy tych regionów: region węzłowy (punktowy), region pasmowy (liniowy) oraz region wielkoprzestrzenny (powierzchniowy).

Turystyczny region węzłowy związany jest $\mathrm{z}$ wykształceniem $\mathrm{w}$ przestrzeni geograficznej wyraźnego rdzenia osadniczego o dominującej funkcji turystycznej, który będąc najczęściej punktem rozrządowym ruchu turystycznego, organizuje wokół otaczającą przestrzeń, podporządkowując ją sobie funkcjonalnie. Turystyczne regiony węzłowe powstają w różnych warunkach środowiska naturalnego i antropologicznego, najczęściej jednak związane są ze środowiskiem górskim czy wodnym (nadmorski, pojezierny), ale również z przestrzenią historyczną. Środowisko naturalne często determinuje kształt przestrzenny regionu węzłowego (kotlina górska, gęsta sieć jezior itd.). Przykładem takiego regionu może być Zakopane organizu- colonization intensified particularly after World War II and still continues including areas unattractive from the point of view of the surrounding environment. The recreational function was later joined by cognitive (industrial archaeology), cultural, academic and commercial (conference, business tourism, etc.) functions, making the city and the surrounding area a multifunctional metropolitan tourist region.

The term peripheral tourist region shows its functionality, and is situated some distance from a large urban centre. Usually the emergence of large peripheral tourist regions depends on the attractiveness of the natural assets (the seaside, mountains, lakes, etc.), which indirectly defines their function (recreational, cognitive, health, etc.). Tourism in peripheral regions often creates quite large settlement units (the Spanish Mediterranean Coast, or the Bulgarian and Romanian Black Sea Coasts) which leads to serious ecological and urban problems in these beautiful areas. Peripheral regions assume very different shapes and sizes.

\section{B. Tourist regions according to their spatial form (shape).}

Another criterion for the division of functional tourist regions can be their spatial form or shape: nodal, linear and areal.

The nodal tourist region is based on a settlement core in geographical space which has a dominant tourist function which usually directs the tourism and functionally controls the space around. Nodal tourist regions occur in various natural and anthropogenic conditions, most often, however, they are associated with mountains or water (seaside and lakes), and with historical space as well. The natural environment often determines the spatial shape of a nodal region (a valley or lake system). An example of such a region is Zakopane which controls the tourist space of both its immediate surrounding area (Rów Podtatrzański) and the whole of Podhale. 
jące przestrzeń turystyczną nie tyko najbliższego zaplecza (Rów Podtatrzański), ale całego Podhala. Przykładami turystycznych regionów węzłowych powstałych i wykreowanych przez przestrzen historyczną może być Toledo w Hiszpanii czy Wenecja we Włoszech.

Szczególnym przypadkiem turystycznych regionów węzłowych są niektóre ośrodki kultu religijnego, organizujące poprzez ruch pielgrzymkowy czy - szerzej - turystykę religijną znaczną przestrzeń. Przykładem takiego regionu węzłowego turystyki religijnej, żyjącego w całości z tej funkcji, może być np. Lourdes we Francji.

Turystyczny region pasmowy. Ten typ regionu związany jest zwykle $\mathrm{z}$ warunkami środowiska przyrodniczego, które określają kształt przestrzenny rozwoju funkcji turystycznej. Klasycznym przykładem tego typu regionów są wybrzeża morskie, np. śródziemnomorskie Hiszpanii, Francji, Włoch, Chorwacji, czy wybrzeża czarnomorskie Bułgarii, Rumunii, Ukrainy, Gruzji. Geneza regionów pasmowych związana jest zwykle z powstaniem regionów węzłowych na podstawie wcześniej istniejących jednostek osadniczych (np. wioski rybackie, małe porty), ale też budowanych na tzw. „surowym korzeniu", których rozwój prowadzi do powstania pasma. W podobny sposób powstają turystyczne regiony pasmowe w górskich dolinach, u podnóża pasm górskich czy wzdłuż dróg komunikacji wodnej (rzek) oraz lądowej (drogi kołowe).

Turystyczne regiony wielkoprzestrzenne mają zwykle charakter wielofunkcyjny (różne typy ruchu turystycznego) i powstają na obszarach zamkniętych granicami naturalnymi, politycznymi lub administracyjnymi. Ten pierwszy przypadek dotyczy zwykle wysp czy wielkich półwyspów, których przestrzeń turystyczna jest tożsama z przestrzenią geograficzną (pełniącą funkcję turystyczna). Przykładem takiego regionu mogą być niektóre wyspy Morza Śródziemnego, np. Ibisa, Minorka, Rodos, czy znaczna część półwyspu Floryda w Stanach Zjednoczonych Ameryki Północnej.

Przykładem regionu wielkoprzestrzennego zamkniętego granicami politycznymi mogą być w Europie np. Szwajcaria, San Marino i Andora, a granicami administracyjnymi czy historycznymi np. Małopolska i Warmia.

\section{Regiony turystyczne w zależności od funkcji ruchu turystycznego.}

Pojęcie ruchu turystycznego rozumianego szeroko (w sensie largo) obejmuje różne cele wyjazdów turystycznych, identyfikowane $w$ przestrzeni
Examples of nodal tourist regions shaped by historical space are Toledo in Spain or Venice in Italy.

A particular case of a nodal tourist region is a religious centre controlling a considerable space through pilgrimage or religious tourism. An example of such a region, totally based on a religious function, for example, is Lourdes in France.

The linear tourist region is usually conditioned by the natural environment which determines the spatial shape of tourist development. Classic examples are sea coasts, e.g. the Mediterranean coasts of Spain, France, Italy, Croatia, or the Black Sea coasts of Bulgaria, Romania, Ukraine, Georgia etc. The origins of linear regions are usually connected with the emergence of nodal regions based on already existing settlement units (e.g. fishing villages or small harbour towns), or those built from scratch the development of which is linear. Linear tourist regions in mountain valleys, at the foot of mountain ranges or along water and land routes (rivers and roads) are created in a similar way. A variation on a linear region are tourist trails, irrespective of the kind of assets which created them (cultural, natural, etc.), on the condition, however, that tourist activity occurs there.

Large-scale tourist regions are usually multifunctional (different types of tourist activity), and occur in environmentally, politically or administratively delimited areas. Natural borders occur, e.g. on islands or large peninsulas whose tourist space is identical to tourist geographical space. Examples here are some islands on the Mediterranean such as Ibiza, Minorca, Rhodes, etc., or a large part of Florida in the USA. Examples of large-space regions delimited politically are Switzerland, San Marino or Andorra, while those with administrative or historical borders - Małopolska or Warmia in Poland.

\section{Tourist regions by tourist function.}

The notion of tourism sensu largo includes a variety of aims for tourist trips 
z funkcją turystyczna. Najogólniej rzecz ujmując, bez wdawania się w zawiłą dyskusję, można mówić o ruchu turystycznym w celach wypoczynkowych i rekreacyjnych, krajoznawczych (poznawczych), zdrowotnych, religijnych, zawodowych, rodzinnych i towarzyskich etc. Przekładając różnorodne rodzaje ruchu turystycznego na przestrzeń geograficzną, na której się one koncentrują, można wyróżnić dwa rodzaje funkcjonalnych regionów turystycznych: regiony wyspecjalizowane i regiony wielofunkcyjne.

Turystyczny region wyspecjalizowany identyfikowany jest zwykle $\mathrm{z}$ regionem jednofunkcyjnym, czyli takim obszarem, gdzie dominuje jeden cel przyjazdów turystycznych. Przykładowo można tu wyróżnić regiony ruchu weekendowego, regiony uzdrowiskowe, regiony turystyki religijnej i krajoznawczej. W praktyce niewiele jest dziś regionów tak wąsko wyspecjalizowanych, zwykle podstawowej funkcji towarzyszą inne; np regiony turystyki zdrowotnej (uzdrowisko, zespoły uzdrowisk), obok głównej funkcji, są obszarami wypoczynkowymi czy krajoznawczymi. Dotyczy to większości tego typu regionów.

Turystyczny region wielofunkcyjny występuje dziś powszechnie, bowiem cechą koncentracji współczesnego ruchu turystycznego na określonym obszarze są jego różnorodne cele. Przyjeżdżając w celach np. wypoczynkowych zwykle staramy się teren naszego pobytu gruntownie poznać (turystyka krajoznawcza), spotkać się ze znajomymi i rodzina, o ile istnieją odpowiednie warunki podreperować nasze zdrowie itd. Współczesne tendencje rozwoju turystyki zmierzają m.in. do tego, aby funkcjonalne regiony turystyczne wzbogacić o nowe funkcje, tworząc $z$ nich wielofunkcyjne obszary turystyczne.

Przedstawiony podział regionów turystycznych i wydzielone typy nie mają charakteru rozłącznego, ale wzajemnie się nakładają i przenikają. Region metropolitalny jest zwykle regionem węzłowym i wielofunkcyjnym, region peryferyjny ma najczęściej kształt liniowy, a w założeniu zwykle bywał regionem wyspecjalizowanym itd. Oznacza to, że przyjęcie za podstawę delimitacji regionu koncentracji ruchu turystycznego na określonej przestrzeni geograficznej zmienia rolę czynników przyrodniczych, historycznych, kulturowych czy szeroko pojętych antropogenicznych z determinujących powstanie regionu na wyjaśniające, nie porządkuje jednak w sposób zadowalający (jak się wydaje) hierarchii typów funkcjonalnych regionów turystycznych. but identified with a tourist function. Generally speaking, there is tourism for recreational, cognitive, health, religious, professional, family, social and other purposes. Considering the different types of tourism in terms of the geographical space in which they take place, we can identify two types of functional tourist regions: specialized and multifunctional.

Specialized tourist regions are usually identified with mono-functional regions, i.e. with areas where one tourist purpose dominates e.g. weekend tourist regions, spas, religious tourism regions, etc. In fact there are not many so highly specialized regions, and usually the basic function is complemented by several more, e.g. spas which apart from their basic function are also recreational areas. It is the same for the majority included in this type.

The multifunctional tourist region occurs commonly nowadays because the concentration of contemporary tourism in a given area is characterized by a variety of purposes. Arriving somewhere to stay, we usually try to learn as much about the area as possible, meet family and friends, improve our health if conditions are appropriate etc. Contemporary trends in tourism development are oriented towards creating new functions in such functional tourist regions, increasing their multi-functionality.

The types of tourist regions presented above should not be considered in isolation because they overlap and are mutually complementary. A metropolitan region is usually a nodal and multifunctional region; a peripheral region is most often linear, and usually began as a specialized region and so on. This means that basing regional delimitation on tourism concentration in a given geographical space, changes the role of the natural, historical, cultural or anthropological factors - from those which determine the emergence of a region to explanatory ones. It does not, however, satisfactorily establish a hierarchy of functional tourist region types. 
Zaprezentowana $w$ tej pracy koncepcja funkcjonalnego regionu turystycznego jako przedmiotu poznania jest zapewne dyskusyjna. Autor, poddając ją publicznej ocenie, ma nadzieję na szerszą naukową dyskusję niezbędną dla dalszego rozwoju metodologicznego nauk czy dyscyplin zajmujących się badawczo turystyką.
The concept of the functional tourist region as an object of study is open to academic discussion which the author considers necessary for further methodological development of those disciplines dealing with tourism.

\section{BIBLIOGRAFIA - BIBLIOGRAPHY}

BAR B., Dolińskı A., 1974, Turystyka, WSziP, Warszawa.

CHOJNICKI Z., 1996, Region w ujęciu geograficzno-systemowym, [w:] T. Czyż (red.), Podstawy regionalizacji geograficznej, Poznań, s. 7-43.

DOMAŃSKI R., 1977, Geografia ekonomiczna, PWN, Warszawa.

DZIEWOŃSKI K., 1967, Teoria regionu ekonomicznego, „Przegląd Geograficzny”, t. 39, z. 1, s. 33-50.

GOtEMBSKI G. (red.), 2002, Metody stymulowania rozwoju turystyki w ujęciu przestrzennym, Wyd. Akademii Ekonomicznej w Poznaniu.

LiJewSki T,, MikuŁowski B., Wyrzykowski J., 1985, Geografia turystyki Polski, PWE, Warszawa.

LISZEWSKI S., 1995, Przestrzeń turystyczna, „Turyzm”, t. 5, z. 2 , s. 87-103.
LISZEWSKI S., BACZWAROW M., 1998, Istota i wlaściwości przestrzeni rekreacyjno-turystycznej, „Turyzm”, t. 8, z. I, s. $39-67$.

LISZEWSKI S., 2002, Przestrzeń turystyczna i osadnictwo turystyczne, [w:] G. Gołembski (red.), Kompendium wiedzy o mieście, PWN, Warszawa, Poznań, s. 77-103.

MILESKA M. J., 1963, Regiony turystyczne Polski. Stan obecny i potencjalne warunki rozwoju. „Prace Geograficzne”, Instytut Geografii PAN, nr 43.

ROGALEWSKI O., 1977, Zagospodarowanie turystyczne, WSziP, Warszawa.

WARSZYŃSKa J., JACKOWSKI A., 1978, Podstawy geografii turyzmu, PWN, Warszawa. 